\title{
Exhaled breath analysis in the differentiation of pneumonia from acute pulmonary oedema
}

\author{
Silvie Prazakova ${ }^{2,3}$, Nadine Elias ${ }^{1}$, Paul S. Thomas ${ }^{1,2}$ and Deborah H. Yates ${ }^{3^{*}}$
}

*Correspondence: deborahy88@hotmail.com

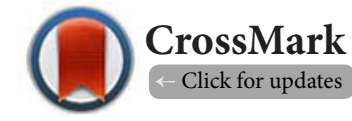

${ }^{1}$ Inflammation and Infection Research Centre, School of Medical Sciences, UNSW, Sydney, NSW, Australia. ${ }^{2}$ Respiratory Medicine, Prince of Wales Hospital, Sydney, NSW, Australia.

${ }^{3}$ Department of Thoracic Medicine, St Vincent's Hospital, Sydney, NSW, Australia.

\begin{abstract}
Introduction: Community-acquired pneumonia (CAP) and acute cardiogenic pulmonary oedema (ACPO) are common clinical conditions requiring hospital admission, but require different treatment. To assess whether exhaled breath analysis can distinguish between these, we measured exhaled breath condensate biomarkers and fractional exhaled nitric oxide $\left(\mathrm{F}_{\mathrm{E}} \mathrm{NO}\right)$ in 14 patients with $\mathrm{CAP}$ and 12 patients with ACPO admitted acutely to hospital via the Emergency Department, comparing profiles with 15 control subjects.

Methods: $\mathrm{F}_{\mathrm{E}} \mathrm{NO}$ was measured using a NO Breath analyser and exhaled breath condensate (EBC) was collected for analysis of EBC biomarkers. $\mathrm{EBC} \mathrm{pH}$ was measured with $\mathrm{pH}$ meter. The EBC biomarkers C-reactive protein (CRP), neopterin and 5N-terminal pro-brain natriuretic peptide (5NT-proBNP) were quantified using enzyme linked immunosorbent assays.

Results: EBC 5NT-proBNP was raised in ACPO, while EBC CRP was raised in CAP. However, neopterin and $\mathrm{pH}$ showed no differences between groups. $\mathrm{F}_{\mathrm{E}} \mathrm{NO}$ levels were significantly higher in $\mathrm{CAP}$ than in $\mathrm{ACPO}(\mathrm{p}=0.03)$.

Conclusions: This study demonstrates that exhaled breath analysis may be useful in assessing the acutely breathless patient, but that even this easy non-invasive technique is difficult for sick patients. More rapid measurements, application of novel biomarkers and combined assessment of several EBC biomarkers are likely to improve diagnostic differentiation in the future.
\end{abstract}

Keywords: Community-acquired pneumonia, acute cardiogenic pulmonary oedema, exhaled breath condensate, exhaled nitric oxide, biomarkers

\section{Introduction}

Pneumonia and acute cardiogenic pulmonary oedema (ACPO) are common acute clinical conditions. Despite their distinct pathophysiology, both may present with similar non-specific symptoms and can be difficult to distinguish radiologically, resulting in misdiagnosis and inappropriate treatment [1]. Methods for distinguishing between these conditions include blood but not exhaled breath biomarkers [2-4]. Exhaled breath analysis is being increasingly used for the clinical diagnosis of conditions ranging from lung cancers to tuberculosis [5-7], and offers the potential of a rapid, easily-performed method for triage and clinical management in the emergency setting.

The advantage of exhaled breath analysis is that it is totally non-invasive and relatively easy to perform even in sick and elderly patients. Exhaled breath condensate (EBC) biomarkers have been assessed in an increasing number of respiratory conditions $[\mathbf{8}, 9]$ including pneumonia $[10]$ and fractional exhaled nitric oxide $\left(\mathrm{F}_{\mathrm{E}} \mathrm{NO}\right)$ is now accepted as a valuable clinical tool in the management of respiratory disorders. Several studies have also indicated that exhaled breath biomarkers may also be useful in assessing cardiac conditions such as cardiac failure [11] and pulmonary hypertension [12].

Community-acquired pneumonia (CAP) is still a common worldwide problem and a common cause of hospital admission. CAP defined is an acute infection of the lung parenchyma by bacteria, viruses or both, manifesting as crackles on auscultation 
and as an infiltrate on radiological imaging; however, these features may not occur in all patients, particularly the elderly or immunosuppressed. In contrast, ACPO occurs when fluid leaks from the pulmonary capillary network into the lung interstitium and alveoli. In ACPO, cardiac dysfunction causes increased pulmonary capillary hydrostatic pressure, forcing fluid into the alveolar and interstitial spaces [13]. Auscultatory crackles and opacities on the chest $\mathrm{x}$-ray occur. Differentiation between ACPO and pneumonia relies upon a careful history, clinical examination and radiographic findings. The latter have poor discriminative value $[1,14]$.

Exhaled breath contains a mixture of volatile and nonvolatile biomarkers. The condensate formed from exhaled breath, EBC, contains a large number of ions, metabolites, and other molecules [15], while the gaseous phase contains volatile organic compounds, a diverse group of carbon-based chemicals [7]. Exhaled breath condensate can be collected using a hand held, simple device which is portable and usable at the bedside; $E B C$ is then snap frozen and later analysed for a wide variety of biomarkers. However, it is possible using modern methodologies to immediately assess potential biomarkers at the bedside, although no studies have currently assessed this.

In this preliminary clinical study, we examined candidate breath biomarkers including CRP and neopterin, measured in $E B C$ and fractional exhaled nitric oxide in a group of patients acutely admitted to hospital. We hypothesised that some breath biomarkers would be raised in CAP but not in $A C P O$ or in a matched control group, while $E B C \mathrm{pH}$ would be decreased [16-19]. We also measured EBC 5N-terminal probrain natriuretic peptide (5NT-proBNP), a marker of cardiac myocyte injury, which is raised in the peripheral blood in heart failure [20,21].

\section{Methods}

\section{Study design and subjects}

Institutional ethics approval (REF SVH H02/004) and written informed consent were obtained. This prospective crosssectional study compared three subject groups: CAP, ACPO and control subjects. Subjects completed a standardised questionnaire, provided $\mathrm{EBC}$ and breath for $\mathrm{F}_{\mathrm{E}} \mathrm{NO}$ analysis.

Participants were admitted to Hospital acutely via the Emergency Department at St Vincent's hospital and selected on the basis of a clinical diagnosis of either CAP or ACPO, made by the admitting doctor in the Department. Patients had to be diagnosed with either disease alone and to have no other respiratory disorder; allocation was made using current international guidelines $[\mathbf{2 2}, \mathbf{2 3}]$ and exclusions were strictly applied to ensure no overlap between groups. Subjects were recruited, as far as possible, within $24 \mathrm{hrs}$ of admission and patients admitted to Intensive Care were excluded. CAP was diagnosed according to the British Thoracic Society's definition: i.e., symptoms and signs consistent with an acute lower respiratory tract infection associated with new chest radiographic shadowing that has no other explanation [22]. ACPO was diagnosed based on characteristic clinical signs as described by the European Society of Cardiology, including orthopnoea, severe respiratory distress, basal fine inspiratory crackles, the presence of radiological opacities and decreased oxygen saturation on room air [23].

The diagnosis was substantiated by retrospective review of hospital case notes after admission, to ensure it had remained unaltered. Exhaled breath analysis was performed as soon as the patient was stable enough, usually within $24 \mathrm{hrs}$ of admission. Control participants were selected on the basis of lack of any known underlying pulmonary or cardiac disease and were matched for age, gender and smoking status. All subjects who had factors recognised to affect exhaled breath biomarkers were excluded, including other lung diseases such as asthma, COPD, bronchiectasis or idiopathic pulmonary fibrosis, and other systemic diseases which could theoretically affect exhaled biomarkers such as connective tissue disorders, uncontrolled hypertension. Smoking habits were documented and for the purposes of the study ex-smokers were defined as those who had not smoked cigarettes for more than 1 year.

\section{Exhaled breath condensate EBC collection}

EBC was collected using a validated custom-made glass tube apparatus according to published recommendations [15]. Subjects rinsed their mouths with water before breathing tidally for 10-12 minutes into a disposable one-way valve mouthpiece (Vitalograph, Buckingham, England). EBC was collected into a glass tube placed on ice and after collection immediately de-aerated with argon gas to displace $\mathrm{CO}_{2}$ and to stabilise the sample.

\section{$E B C p H$}

$\mathrm{EBC} \mathrm{pH}$ for each subject was measured using a hand-held $\mathrm{pH}$ meter (Hach, Colorado, USA) at three different time points: immediately prior to de-aeration, immediately following deaeration and after a freeze-thaw cycle to ensure that the effects of EBC processing and storage were taken into account [24].

\section{EBC biomarker analysis}

EBC biomarker analysis was undertaken using enzyme linked immunosorbent assays. Neopterin was measured using an enzyme linked immunosorbent assay (ELISA, GenWay Biotech, San Diego, USA) with a lower limit of detection (LLOD) of $0.7 \mathrm{nmol} / \mathrm{l}$. NT-proBNP was measured using an enzyme immunoassay (EIA, Alpco Diagnostics, Salem, USA) with a LLOD of $5 \mathrm{fmol} / \mathrm{ml}$. CRP was measured by ELISA (Invitrogen, Camarillo, USA) with a LLOD of $1.84 \mathrm{pg} / \mathrm{ml}$ following optimisation of the standard curve by the addition of more standard points. Absorption levels were determined spectrophotometrically (Molecular Devices, Surrey, UK) using the specified wavelengths.

\section{EBC data analysis}

$A D^{\prime}$ Agostino\& Pearson omnibus normality test was followed by 
either one way analysis of variance (ANOVA) with Bonferroni's multiple comparison post-hoc test or the Kruskal-Wallis test with Dunn's post-hoc test. Data were expressed as means \pm standard errors (SE) for parametric data and as median (interquartile range) for nonparametric data. Significance was set at $p<0.05$. A value of one-half of the LLOD was assigned to all undetectable values.

\section{Fractional exhaled nitric oxide}

$\mathrm{F}_{\mathrm{E}} \mathrm{NO}$ was measured in accordance with published guidelines [25]. Subjects exhaled into the NO breath analyser (Bedfont Scientific Ltd, Kent, UK) for 15 seconds at a pressure of $15 \mathrm{~cm} \mathrm{H}_{2} \mathrm{O}$, to close the soft palate and thus avoid nasal NO contamination. An average was taken of 3 sequential readings if they were within a $10 \%$ range. A flow rate of $0.05 \mathrm{~L} / \mathrm{second}$ was used.

\section{Results}

\section{Subject characteristics}

Fourteen subjects with CAP, twelve subjects with ACPO and fifteen healthy controls were able to provide EBC samples, and clinical characteristics are shown in Table 1. All subjects provided $\mathrm{EBC}$ and also had their $\mathrm{F}_{\mathrm{E}} \mathrm{NO}$ measured, except for one subject with CAP.

Patients with concomitant diseases had been excluded from the study, so none had any evidence of respiratory disorders such as asthma or bronchiectasis. Subjects were younger than the usual patient with CAP, probably reflecting the above exclusion factor. No significant differences were found between study groups, including smoking habits.

\section{Exhaled breath condensate}

Although 20 subjects were recruited in both disease groups, not all were able to complete $\mathrm{EBC}$ collection and $\mathrm{F}_{\mathrm{E}} \mathrm{NO}$ analysis.

Table 1. Characteristics of the cohort providing EBC.

\begin{tabular}{lllll}
\hline & CAP & ACPO & Controls & $\begin{array}{l}\text { Statistical } \\
\text { difference }\end{array}$ \\
\hline Subjects (n) & $\mathbf{1 4}$ & $\mathbf{1 2}$ & $\mathbf{1 5}$ & \\
\hline $\begin{array}{l}\text { Age (years) } \\
\text { mean } \pm \text { SE }\end{array}$ & $59.43 \pm 5.689$ & $54.50 \pm 5.804$ & $56.33 \pm 5.414$ & $\begin{array}{l}\text { ANOVA } \\
\mathrm{p}=0.83\end{array}$ \\
$\begin{array}{l}\mathrm{BMI}\left(\mathrm{kg} / \mathrm{m}^{2}\right) \\
\text { mean } \pm \mathrm{SE}\end{array}$ & $24.87 \pm 1.311$ & $28.41 \pm 1.817$ & $27.05 \pm 1.158$ & $\begin{array}{l}\text { ANOVA } \\
\mathrm{p}=0.24\end{array}$ \\
$\begin{array}{l}\text { Gender } \\
\text { (male/female) }\end{array}$ & $12 / 2$ & $7 / 5$ & $11 / 4$ & $\begin{array}{l}\text { Fisher's } \\
\text { exact test } \\
\mathrm{p}=0.31\end{array}$ \\
$\begin{array}{l}\text { Smoking } \\
\text { status } \\
\text { (non/ex/ } \\
\text { current) }\end{array}$ & $6 / 4 / 4$ & $5 / 4 / 3$ & $10 / 3 / 2$ & $\begin{array}{l}\text { Fisher's } \\
\text { exact test } \\
\mathrm{p}=0.60\end{array}$ \\
\hline
\end{tabular}

ACPO: Acute cardiogenic pulmonary oedema; CAP: Community acquired pneumonia; BMI: Body mass index; n: Number of subjects; SE: Standard error. Smoking status was defined as nonsmoking when subject had never smoked, ex-smoker when subject had not smoked for twelve months and a current smoker if subject was still smoking or had quit within the preceding eleven months.
This was primarily due to breathlessness in the acutely ill patients. Patients found it difficult to complete the EBC collection, which requires at least 10 minutes breathing into the simple collection device, and asked to terminate the procedure early before sufficient EBC had been collected.

\section{$E B C p H$}

EBC was available in 14 subjects with CAP, 12 with $A C P O$ and 15 healthy controls $(n=41)$. No significant differences in mean $\mathrm{EBC} \mathrm{pH}$ were found between the three groups. This applied before de-aeration $(p=0.24)$, after de-aeration $(p=0.51)$, and after a freeze-thaw cycle ( $p=0.17$ ) of EBC (Figure 1). In 2 CAP subjects, EBC pH could not be accurately measured after deaeration due to technical problems.

\section{EBC biomarkers}

EBC CRP was detected in more subjects with CAP $(7 / 14 ; 50 \%)$, than in those with ACPO $(4 / 12 ; 30 \%)$ and controls $(1 / 15 ; 6.6 \%$; $p=0.03$ for differences between groups). The remaining subjects had levels below the LLOD. Median (interquartile range) CRP values were: CAP 1.188 (0.920-2.565) pg/ml; ACPO 0.920 (0.920$11.340) \mathrm{pg} / \mathrm{ml}$; controls $0.920(0.920-0.920) \mathrm{pg} / \mathrm{ml}(\mathrm{p}=0.07$, Figure 2a). On clinical review after recovery, the four ACPO subjects who had high CRP levels also had other clinical conditions (renal failure, Pseudomonas infection, chronic sinusitis) which may have affected CRP levels other than their clinical presenting problem. After removing these four subjects from the analysis there was a significant difference in CRP levels between subjects with CAP and other groups $(p=0.009)$. To assess if EBC CRP reflects the severity of pneumonia, EBC CRP levels were correlated with total white blood cell count. We found no significant positive correlation between total white blood cell count and EBC CRP levels in the pneumonia group $(r=0.08, p=0.78)$. Ten subjects with ACPO and 14 subjects with CAP had serum CRP levels measured by the hospital laboratory. There was no correlation between serum CRP and EBC CRP $(r=-0.1, p=0.63)$.

Neopterin was detectable in all groups but there were no significant differences between groups (11/14 CAP subjects (78.6\%), 11/12 ACPO (91.7\%) and 11/15 controls (73.3\%, $\mathrm{p}=0.54$ ). Median (interquartile range) neopterin values were: CAP 2.478 (1.279-3.721) nmol/L; ACPO 2.338 (1.939-3.311) $\mathrm{nmol} / \mathrm{L}$; controls $1.644(0.350-3.421) \mathrm{nmol} / \mathrm{L}(\mathrm{p}=0.64$, Figure $2 \mathrm{~b})$.

5NT-proBNP was detected in 6/12 ACPO subjects (50\%), $4 / 14$ CAP subjects $(28.6 \%)$ and $12 / 15$ controls $(80 \%, p=0.02)$. Median (interquartile range) 5NT-proBNP values were: CAP 2.5 (2.5-17.71) fmol $/ \mathrm{ml} ;$ ACPO12.85 (2.5-976.2) fmol $/ \mathrm{ml}$; controls $30.18(3.467-184.7) \mathrm{fmol} / \mathrm{ml}(p=0.04$, Figure $2 \mathrm{c}$ ) and post-hoc test analysis showed a significant difference between the controls and CAP group, with levels higher in the controls.

\section{Exhaled nitric oxide}

$F_{E} N O$ was measured in CAP $(n=13), A C P O(n=12)$ and control $(n=15)$ subjects and mean values were: CAP $19.36 \pm 3.662$ 

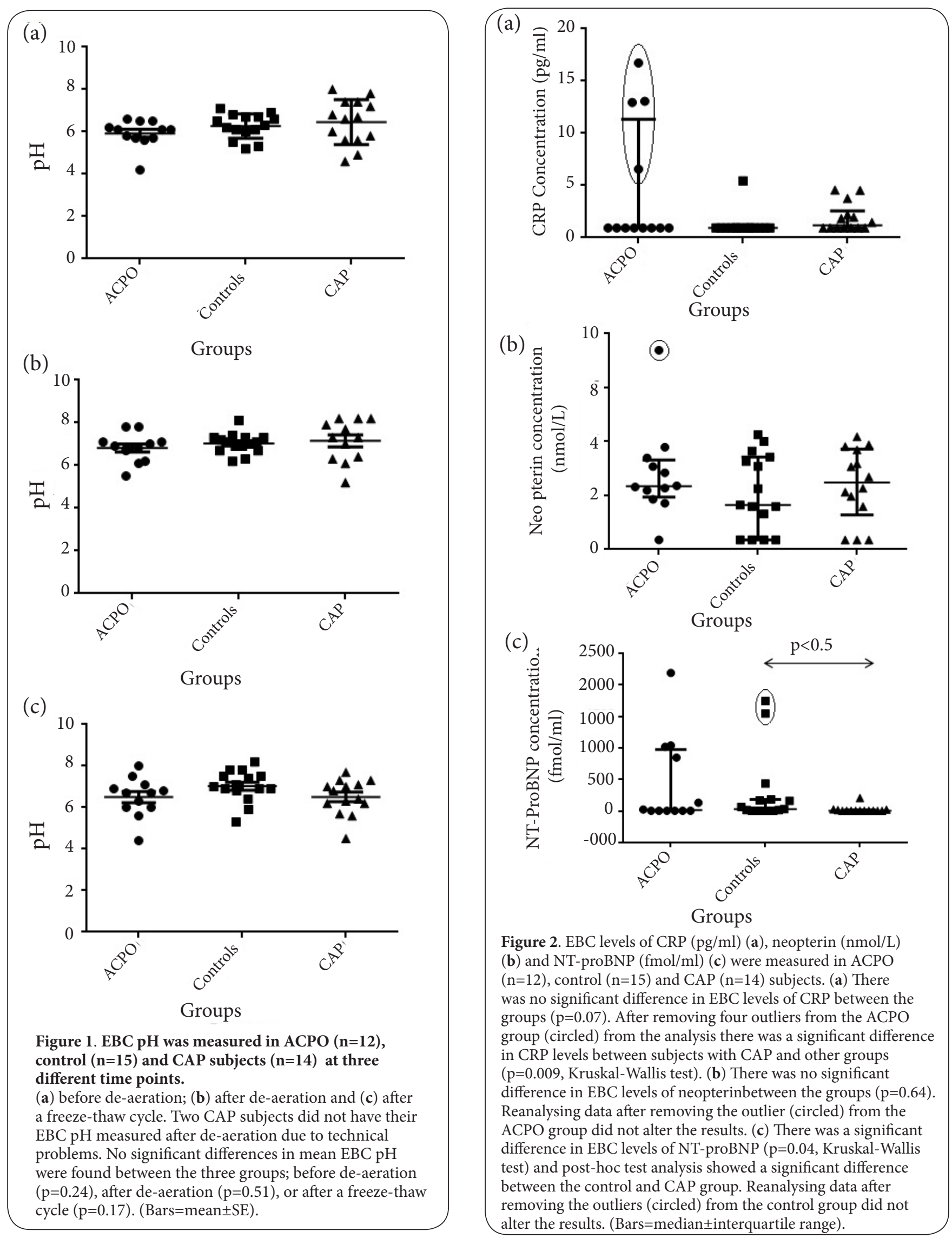
parts per billion (ppb); ACPO 11.51 $1.737 \mathrm{ppb}$; controls $13.88 \pm 1.783 \mathrm{ppb}$. The data have been logarithmically transformed. Exhaled NO levels were significantly higher in the CAP group compared to the ACPO group ( $p=0.03$ ). No significant difference was found between the ACPO group and controls (Figure 3).

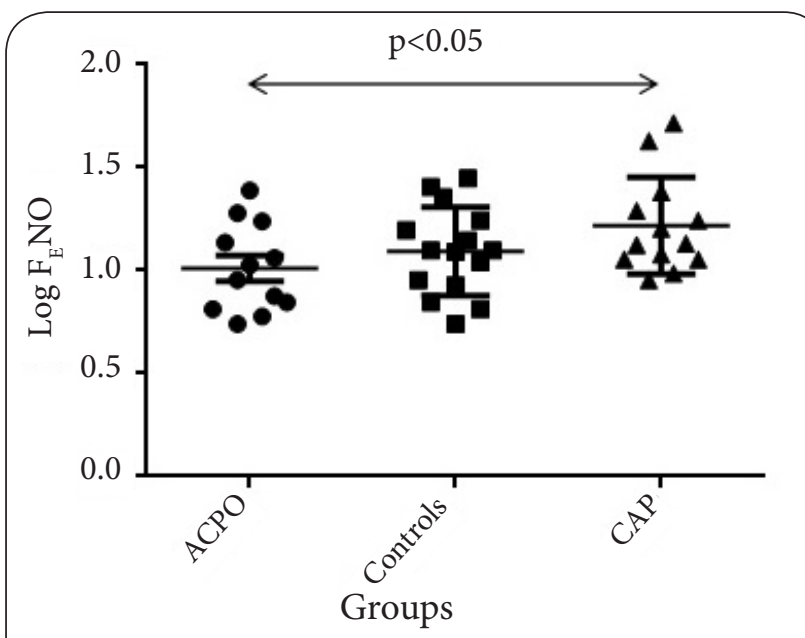

Figure 3. Log transformed levels of fractional exhaled nitric oxide $\left(\mathrm{F}_{\mathrm{E}} \mathrm{NO}\right)$ in $\mathrm{ACPO}$, control and CAP subjects. $\mathrm{F}_{\mathrm{E}} \mathrm{NO}$ was measured in ACPO $(\mathrm{n}=12)$, control $(\mathrm{n}=15)$ and CAP $(n=13)$ subjects. $\mathrm{F}_{\mathrm{E}} \mathrm{NO}$ levels were significantly in the CAP group compared to the ACPO group $(\mathrm{p}=0.03)$ but no significant difference was found when compared to control group. (Bars=mean $\pm \mathrm{SE})$.

\section{Discussion}

This study is the first to attempt to distinguish between CAP and ACPO using exhaled breath analysis in acutely ill patients. These patients are difficult to study and there is very limited research in this area. Until now, research has focussed upon serum biomarkers, particularly CRP, derived from blood samples. If exhaled breath samples were feasible and accurate, this procedure would be much less invasive and easier for the patient. If these could be collected during an acute attack of dyspnoea by using, for example, a common clinical device e.g., a respiratory mask, and at the bedside, these might provide very valuable clinical information and could possibly be used in situations where blood collection is difficult. However, preliminary data on EBC in this situation is first required, and thus we aimed initially to collect data on $\mathrm{EBC}$ in the acute situation using the standard collection methods before embarking on a larger study. In practice, even when breath collection was delayed by up to 24 hours to facilitate patient participation, we found that patients were too breathless to willingly complete breath collection for research purposes, but that once samples were collected, several useful biomarkers could be identified.

We measured several well known blood biomarkers in order to define an EBC profile which might distinguish accurately between $A C P O$ and pneumonia in these patients, including $\mathrm{EBC} \mathrm{pH}, \mathrm{CRP}$, neopterin, and 5NT-proBNP. We also measured fractional exhaled nitric oxide, which is known to be raised in acute inflammatory conditions such as pneumonia in the acute setting.

5NT-proBNP is a product of the pro-hormone brain natriuretic peptide which is released by cardiac myocytes when the ventricles are subject to haemodynamic stress [26] and is the current serological diagnostic marker of heart failure [21]. There is now a large literature on 5NT-proBNP in heart failure, which has clearly demonstrated that a normal blood 5NT-proBNP excludes cardiac failure in $99 \%$ of cases $[20,21]$. We measured EBC 5NT-proBNP in EBC in acutely dyspnoeic patients, and found that ACPO group had the highest numerical mean value, as expected. Levels were also statistically different between the control and CAP groups, with a clear difference between the groups with CAP and ACPO. However, levels in our controls were higher than expected, with two outliers with values clearly above the others. We are unsure as to why these levels were raised in these two volunteers; review of co-morbidities in these cases found none other than one patient with controlled hypertension, which is not thought to affect basal levels of serum NT-proBNP [27]. Unfortunately, we were not able to collect blood 5NT-proBNP in controls which would have been of interest; it is possible that the raised EBC levels in the controls were due to laboratory factors or storage, or else that these subjects have some unrecognised condition. The normal limits for EBC 5NT-proBNP have not yet been assessed. Thus, EBC 5NT-proBNP may have potential clinical applicability in this diagnostic setting but requires further evaluation. Other exhaled breath biomarkers of heart failure such as EBC acetone [28] have been described and dual measurement might increase specificity in future studies.

There are a number of studies now which confirm that $\mathrm{F}_{\mathrm{E}} \mathrm{NO}$ is increased in CAP [25], probably due to inflammatory cytokines acting on inducible NO synthase [29]. $\mathrm{F}_{\mathrm{E}} \mathrm{NO}$ is high in ventilator-acquired pneumonia (VAP) [18] and eosinophilic pneumonia [30]; however, not all studies have had similarly high $\mathrm{F}_{\mathrm{E}} \mathrm{NO}$ levels [31]. In our study, $\mathrm{F}_{\mathrm{E}} \mathrm{NO}$ was higher in CAP compared to ACPO, and adequately distinguished between the conditions. However, the difference between CAP and control subjects fell just short of statistical significance; it is possible that this reflects differences in severity of pneumonia, or else a treatment effect because antibiotics are given intravenously early (within 2 hours) in CAP in our Emergency Department. Mean levels in control subjects were within the published normal range (8-14ppb) [29], but levels in CAP (19.4 $\mathrm{ppb}$ ) were not as high as in previous studies of VAP (56 ppb) [32] and eosinophilic pneumonia (48 ppb) [30], which may account for the lack of statistical significance.

We anticipated that CRP, an acute phase protein synthesised in the liver in response to pro-inflammatory cytokines, might be raised in CAP but not in ACPO. EBC CRP has been 
previously measured although not in pneumonia [33]. We found that EBC CRP was detectable in a larger number of cases with CAP compared to ACPO and control groups $(p=0.03)$. Differences between groups did not reach statistical significance. The lack of significance was contributed towards by unexpectedly increased levels in the ACPO group. Several of these subjects were overweight, and three had other clinical conditions (mild renal failure, Pseudomonas infection, chronic sinusitis). Serum CRP have been shown to be increased in obesity [34], but should not increase to high levels with bacterial colonisation rather than pneumonia. CRP could be increased in EBC in obesity, but this has not been examined. EBC CRP remains a potentially useful biomarker but as always in the acute clinical situation, multiple pathologies can co-exist and individual patient factors may alter results.

Neopterin is a non-specific marker of cell-mediated immunity and cytotoxic T lymphocyte activity [35]. Serum neopterin has been previously studied in CAP [36], and EBC neopterin can be detected in patients with infective exacerbations of asthma and COPD [8]. We detected neopterin in most EBC samples but the levels did not differ between the groups. The only other study evaluating EBC neopterin compared patients with acute and stable obstructive lung disease, and also failed to find a difference in EBC levels, but suggested that sputum neopterin might be more useful [8]. It is possible that EBC neopterin levels are too low for a useful clinical measurement. EBC $\mathrm{pH}$ levels are usually a robust discriminator between acute and stable respiratory disease [8], and reflect inflammation in obstructive lung diseases $[19,37]$. We found however that EBC pH did not differentiate between groups in our study.

There are several possible confounding factors in our study, which relate to real clinical issues and are therefore valuable to identify for future clinical research. One factor was the delay between initial presentation of these acutely ill breathless patients and EBC collection. This was included as part of the research plan for both ethical and practical reasons. Both CAP and $A C P O$ require emergency treatment, which was given within hours of presentation. EBC was therefore collected after treatment had commenced, usually within $24 \mathrm{hrs}$, and once the patient had been stabilised. Serum CRP levels fall rapidly (within $24 \mathrm{hrs}$ ) with commencement of appropriate antibiotic therapy [1]; this may also apply to EBC CRP and neopterin and $\mathrm{pH}$, but no data are yet available. Similarly, EBC NT-proBNP would also be expected to change rapidly, but has not been previously assessed. Clinical treatment must take priority over research procedures but immediate collection and comparison with serum values would be of interest.

Our study was probably also limited by the small sample size, which we acknowledge. It was, however, only planned as a preliminary study. Power calculations in future studies need to be based on individual biomarker reproducibility, which has not yet been assessed in EBC for the biomarkers we studied. A number of samples had levels below the LLOD of the assays, which were actually designed for serum not for EBC. This aspect could also possibly be improved by concentrating EBC through lyophilisation, which has proved successful in other studies [38], or by new assays.

\section{Conclusions}

In summary, our study has shown that exhaled breath analysis in the acute emergency setting is promising, but not yet currently sufficiently sensitive or specific to fulfil clinical needs. Many patients are simply too unwell to be studied acutely, at least for research purposes. EBC CRP, NT-proBNP and $\mathrm{F}_{\mathrm{E}} \mathrm{NO}$ seem promising markers, but differences in breath levels between diseases do not seem large enough to allow good discrimination when measured at 24 hours after acute presentation. Currently, most biomarker assays are not available acutely other than CRP, which is available as a bedside test (QuickRead CRP), and biomarkers also need further evaluation in EBC. Development of rapid accurate assays would be potentially useful. In practice, clinical diagnosis relies on the assimilation of multiple types of information and thus in the future, analysis of combinations of biomarkers as well as novel biomarkers may be required to allow diagnostic accuracy and to achieve the aim of giving a patient an immediate bedside diagnosis without invasive methods.

\section{Competing interests}

The authors declare that they have no competing interests.

\section{Authors' contributions}

\begin{tabular}{|l|c|c|c|c|}
\hline Authors' contributions & SP & NE & PST & DHY \\
\hline Research concept and design & -- & -- & $\checkmark$ & $\checkmark$ \\
\hline Collection and/or assembly of data & $\checkmark$ & $\checkmark$ & -- & -- \\
\hline Data analysis and interpretation & $\checkmark$ & $\checkmark$ & $\checkmark$ & $\checkmark$ \\
\hline Writing the article & $\checkmark$ & $\checkmark$ & -- & -- \\
\hline Critical revision of the article & -- & -- & $\checkmark$ & $\checkmark$ \\
\hline Final approval of article & $\checkmark$ & $\checkmark$ & $\checkmark$ & $\checkmark$ \\
\hline Statistical analysis & $\checkmark$ & $\checkmark$ & -- & -- \\
\hline
\end{tabular}

\section{Acknowledgement}

This study was supported by the Lesley Pockley Clinical Research Trust. The authors would like to thank the participants who kindly volunteered for this study, and the staff of the Departments of Thoracic Medicine at St Vincent's and Prince of Wales Hospitals.

\section{Publication history}

Editors: Yousser Mohammad, Tishreen University, Syria.

EIC: Victor J. Thannickal, University of Alabama at Birmingham, USA. Received: 29-May-2015 Final Revised: 07-Jul-2015

Accepted: 03-Aug-2015 Published: 10-Aug-2015

\section{References}

1. Castro-Guardiola A, Armengou-Arxe A, Viejo-Rodriguez A, PenarrojaMatutano $G$ and Garcia-Bragado F. Differential diagnosis between community-acquired pneumonia and non-pneumonia diseases of the chest in the emergency ward. Eur J Intern Med. 2000; 11:334-339. | Article I PubMed

2. Christ M, Laule K, Klima T, Hochholzer W, Breidthardt T, Perruchoud AP and Mueller C. Multimarker strategy for risk prediction in patients 
presenting with acute dyspnea to the emergency department. Int $J$ Cardiol. 2008; 126:73-8. | Article | PubMed

3. Joffe E, Justo D, Mashav N, Swartzon M, Gur H, Berliner S and Paran Y. C-reactive protein to distinguish pneumonia from acute decompensated heart failure. Clin Biochem. 2009; 42:1628-34. | Article | PubMed

4. Morrison LK, Harrison A, Krishnaswamy P, Kazanegra R, Clopton P and Maisel A. Utility of a rapid B-natriuretic peptide assay in differentiating congestive heart failure from lung disease in patients presenting with dyspnea. J Am Coll Cardiol. 2002; 39:202-9. | Article | PubMed

5. Phillips M, Altorki N, Austin JH, Cameron RB, Cataneo RN, Greenberg J, Kloss R, Maxfield RA, Munawar MI, Pass HI, Rashid A, Rom WN and Schmitt $P$. Prediction of lung cancer using volatile biomarkers in breath. Cancer Biomark. 2007; 3:95-109. | Article | PubMed

6. Nakhleh MK, Jeries R, Gharra A, Binder A, Broza YY, Pascoe M, Dheda $\mathrm{K}$ and Haick $\mathrm{H}$. Detecting active pulmonary tuberculosis with a breath test using nanomaterial-based sensors. Eur Respir J. 2014; 43:1522-5. | Article | PubMed

7. Chapman EA, Thomas PS, Stone E, Lewis $C$ and Yates DH. A breath test for malignant mesothelioma using an electronic nose. Eur Respir J. 2012; 40:448-54. | Article | PubMed

8. Warwick G, Thomas PS and Yates DH. Non-invasive biomarkers in exacerbations of obstructive lung disease. Respirology. 2013; 18:874-84. | Article | PubMed

9. Chow S, Thomas PS, Malouf M and Yates DH. Exhaled breath condensate (EBC) biomarkers in pulmonary fibrosis. J Breath Res. 2012; 6:016004. | Article | PubMed

10. Huang J KS, Singanayagam A, George P M, Kon O M, Takataa M and Hanna G B. Exhaled breath acetone for therapeutic monitoring in pneumonia using selected ion flow tube mass spectrometry (SIFT-MS). Anal Methods. 2013; 5:3807-3810. | Article

11. Pappas $L$ and Filippatos $G$. [Pulmonary congestion in acute heart failure: from hemodynamics to lung injury and barrier dysfunction]. Rev Esp Cardiol. 2011; 64:735-8. | Article | PubMed

12. Warwick G, Kotlyar E, Chow S, Thomas PS and Yates DH. Exhaled breath condensate in pulmonary arterial hypertension. J Breath Res. 2012; 6:036006. | Article | PubMed

13. Ware LB and Matthay MA. Clinical practice. Acute pulmonary edema. $N$ Eng/ J Med. 2005; 353:2788-96. | Article | PubMed

14. Edoute $Y$, Roguin A, Behar D and Reisner SA. Prospective evaluation of pulmonary edema. Crit Care Med. 2000; 28:330-5. | Article | PubMed

15. Horvath I, Hunt J, Barnes PJ, Alving K, Antczak A, Baraldi E, Becher G, van Beurden WJ, Corradi M, Dekhuijzen R and Dweik RA et al. Exhaled breath condensate: methodological recommendations and unresolved questions. Eur Respir J. 2005; 26:523-48. | Article | PubMed

16. Chalmers JD, Singanayagam A and Hill AT. C-reactive protein is an independent predictor of severity in community-acquired pneumonia. Am J Med. 2008; 121:219-25. | Article | PubMed

17. Prat C, Dominguez J, Andreo F, Blanco S, Pallares A, Cuchillo F, Ramil C, Ruiz-Manzano $J$ and Ausina V. Procalcitonin and neopterin correlation with aetiology and severity of pneumonia. J Infect. 2006; 52:169-77. I Article | PubMed

18. Adrie C, Monchi M, Dinh-Xuan AT, Dall'Ava-Santucci J, Dhainaut JF and Pinsky MR. Exhaled and nasal nitric oxide as a marker of pneumonia in ventilated patients. Am J Respir Crit Care Med. 2001; 163:1143-9. | Article I PubMed

19. Kostikas K, Papatheodorou G, Ganas K, Psathakis K, Panagou P and Loukides $\mathrm{S}$. $\mathrm{pH}$ in expired breath condensate of patients with inflammatory airway diseases. Am J Respir Crit Care Med. 2002; 165:1364-70. | Article | PubMed

20. Januzzi JL, Jr., Camargo CA, Anwaruddin S, Baggish AL, Chen AA, Krauser DG, Tung R, Cameron R, Nagurney JT, Chae CU, Lloyd-Jones DM, Brown $D F$, Foran-Melanson S, Sluss PM, Lee-Lewandrowski E and Lewandrowski $\mathrm{KB}$. The $\mathrm{N}$-terminal Pro-BNP investigation of dyspnea in the emergency department (PRIDE) study. Am J Cardiol. 2005; 95:948-54. | Article | PubMed

21. Robaei D, Koe L, Bais R, Gould I, Stewart T and Tofler GH. Effect of NT-proBNP testing on diagnostic certainty in patients admitted to the emergency department with possible heart failure. Ann Clin Biochem. 2011; 48:212-7. | Article | PubMed

22. Lim WS, Baudouin SV, George RC, Hill AT, Jamieson C, Le Jeune I,
Macfarlane JT, Read RC, Roberts HJ, Levy ML, Wani M and Woodhead MA. BTS guidelines for the management of community acquired pneumonia in adults: update 2009. Thorax. 2009; 64 Suppl 3:iii1-55. | Article | PubMed

23. Nieminen MS, Bohm M, Cowie MR, Drexler H, Filippatos GS, Jondeau G, Hasin Y, Lopez-Sendon J, Mebazaa A and Metra M et al. Executive summary of the guidelines on the diagnosis and treatment of acute heart failure: the Task Force on Acute Heart Failure of the European Society of Cardiology. Eur Heart J. 2005; 26:384-416. | Article | PubMed

24. Lin JL, Bonnichsen MH and Thomas PS. Standardization of exhaled breath condensate: effects of different de-aeration protocols on $\mathrm{pH}$ and $\mathrm{H}(2) \mathrm{O}(2)$ concentrations. J Breath Res. 2011; 5:011001. | Article | PubMed

25. ATS/ERS recommendations for standardized procedures for the online and offline measurement of exhaled lower respiratory nitric oxide and nasal nitric oxide, 2005. Am J Respir Crit Care Med. 2005; 171:912-30. I Article I PubMed

26. Braunwald E. Biomarkers in heart failure. N Engl J Med. 2008; 358:214859. | Article | PubMed

27. Talwar S, Siebenhofer A, Williams B and Ng L. Influence of hypertension, left ventricular hypertrophy, and left ventricular systolic dysfunction on plasma N terminal proBNP. Heart. 2000; 83:278-82. | Article | PubMed Abstract | PubMed Full Text

28. Marcondes-Braga FG, Gutz IG, Batista GL, Saldiva PH, Ayub-Ferreira SM, Issa VS, Mangini S, Bocchi EA and Bacal F. Exhaled acetone as a new biomaker of heart failure severity. Chest. 2012; 142:457-66. | Article | PubMed

29. Yates DH. Role of exhaled nitric oxide in asthma. Immunol Cell Biol. 2001; 79:178-90. | Article | PubMed

30. Carraro S, Andreola B, Alinovi R, Corradi M, Freo L, Da Dalt L and Baraldi E. Exhaled leukotriene B4 in children with community acquired pneumonia. Pediatr Pulmonol. 2008; 43:982-6. | Article | PubMed

31. Lee JE, Rhee CK, Lim JH, Lee SM, Shim YS, Lee CT and Lee SW. Fraction of exhaled nitric oxide in patients with acute eosinophilic pneumonia. Chest. 2012; 141:1267-72. | Article | PubMed

32. Kwak HJ KS, Kim TH, Yoon HJ, Shin DH, Park SS and Sohn JW. Exhaled Nitric Oxide in Patients with Ventilator Associated Pneumonia. Korean J Crit Care Med. 2012; 27:82-88. | Article

33. Zietkowski Z, Tomasiak-Lozowska MM, Skiepko R, Mroczko B, Szmitkowski $\mathrm{M}$ and Bodzenta-Lukaszyk $\mathrm{A}$. High-sensitivity C-reactive protein in the exhaled breath condensate and serum in stable and unstable asthma. Respir Med. 2009; 103:379-85. | Article | PubMed

34. Visser M, Bouter LM, McQuillan GM, Wener MH and Harris TB. Elevated C-reactive protein levels in overweight and obese adults. JAMA. 1999; 282:2131-5. | Article | PubMed

35. Murr C, Widner B, Wirleitner B and Fuchs D. Neopterin as a marker for immune system activation. Curr Drug Metab. 2002; 3:175-87. | Article | PubMed

36. Ip M, Rainer TH, Lee N, Chan C, Chau SS, Leung W, Leung MF, Tam TK, Antonio GE, Lui G, Lau TK, Hui DS, Fuchs D, Renneberg R and Chan PK. Value of serum procalcitonin, neopterin, and C-reactive protein in differentiating bacterial from viral etiologies in patients presenting with lower respiratory tract infections. Diagn Microbiol Infect Dis. 2007; 59:131-6. | Article | PubMed

37. Ojoo JC, Mulrennan SA, Kastelik JA, Morice AH and Redington AE. Exhaled breath condensate $\mathrm{pH}$ and exhaled nitric oxide in allergic asthma and in cystic fibrosis. Thorax. 2005; 60:22-6. | Article | PubMed Abstract | PubMed Full Text

38. Edme JL, Tellart AS, Launay D, Neviere R, Grutzmacher C, Boulenguez C, Labalette M, Hachulla E, Hatron PY, Dessaint JP, Matran R and Sobaszek A. Cytokine concentrations in exhaled breath condensates in systemic sclerosis. Inflamm Res. 2008; 57:151-6. | Article | PubMed

\section{Citation:}

Prazakova S, Elias N, Thomas PS and Yates DH. Exhaled breath analysis in the differentiation of pneumonia from acute pulmonary oedema. Pulmonol Respir Res. 2015; 3:3. http://dx.doi.org/10.7243/2053-6739-3-3 